\author{
Marinka ŠIMIĆ \\ Staroslavenski institut \\ Zagreb \\ marinka.simic@stin.hr
}

UDK 272-282.7:003.349.1

811.163.42'373

Izvorni znanstveni članak

Primljen: 30. travnja 2019.

Prihvaćen: 9. listopada 2019.

\title{
MORAVIZMI U DRUGOM BERAMSKOM (LJUBLJANSKOM) BREVIJARU ${ }^{1}$
}

Prvotni je prijevod starocrkvenoslavenskih biblijskih tekstova kao što je poznato, posebice aprakosa, psaltira i apostola izmijenjen u Moravskoj premda je još uvijek neistraženo u kojoj mjeri. Određeni je broj leksema vjerojatno preuzet iz zapadnoslavenskih jezika. Iako u povijesnim izvorima za najstarije ćirilometodsko razdoblje slavenske pismenosti nema potvrda o dodiru Hrvata s moravskom misijom, može se pretpostaviti da je do tog utjecaja došlo nakon protjerivanja slavenskih učenika iz Moravske ako ne i ranije. To uz ostalo potvrđuju i očuvani moravizmi u hrvatskoglagoljskim tekstovima, odnosno riječi koje su u kanonskim starocrkvenoslavenskim tekstovima arhaizmi. Većina njih pojavljuje se u našim starijim rukopisima, fra-

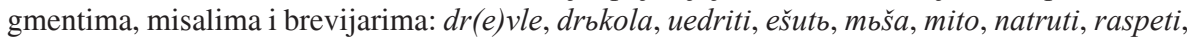
rêsnota, siko, sbnbmb, šui itd. Neki se od tih leksema pojavljuju i u Drugome beramskom brevijaru: drev'lê, dreselı, drkola, kokošb, pastirb, pênezb, izvedenice od korijena rêsn- itd. Iako problem leksičkih moravizama u hrvatskoglagoljskim spomenicima nije posve usustavljen i definiran, autorica izlaže popis mogućih moravizama u Drugom beramskom (ljubljanskom) brevijaru uz analizu njihova značenja. Između ostaloga, istražuje se postoji li razlika u broju moravizama između 1. i 2. dijela brevijara, kao i kakav je odnos između ovog sloja leksema u ovom rukopisu i najstarijih hrvatskoglagoljskih fragmenata.

Ključne riječi: moravizmi, leksik, crkvenoslavenski jezik hrvatske redakcije, Drugi beramski (ljubljanski) brevijar

\section{UVOD}

Tekstološkim je istraživanjem hrvatskoglagoljskih spomenika utvrđeno da čuvaju vrlo staru ćirilometodsku tradiciju i da su je crpli sa sjevera, još iz veli-

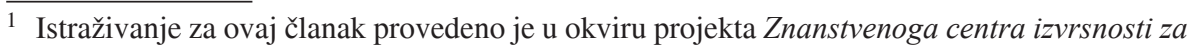
hrvatsko glagoljaštvo Staroslavenskoga instituta u Zagrebu. V. https://beram.stin.hr. 
komoravskoga razdoblja, ali također i s jugoistoka, posebice iz makedonskih izvora. ${ }^{2}$ Drugim riječima, danas prevladava mišljenje da je ćirilometodska tradicija u Hrvatsku dolazila iz dva smjera: sa sjevera iz Moravske i Panonije, a potom s juga iz Bugarske i Makedonije. ${ }^{3}$ To znači da se u hrvatskoglagoljskim liturgijskim knjigama mogu razlučiti najmanje tri tekstovna sloja: tragovi izvornoga ćirilometodskoga prijevoda bogoslužnih knjiga, tragovi Metodova cjelovitoga prijevoda Biblije te prijevodi prema latinskoj Vulgati. Uočeno je međutim da postoji i četvrti sloj, tj. da su u hrvatskoglagoljskim tekstovima razmjerno brojne i potvrde elemenata tipičnih za Preslavsku književnu školu, što znači da južnim putem preko Ohrida, Zete, Huma i Bosne nisu dolazili samo tekstovi nastali u Ohridu, nego i oni pisani na istočnom bugarskom području. ${ }^{4}$

Kad se počeo upotrebljavati prvi slavenski književni jezik na moravskom tlu dobiva prve nemakedonske osobine lokalnoga narodnog jezika, posebice u leksiku i time postaje službeni zajednički slavenski jezik. Širi i nadnarodnosni karakter taj jezik dobiva zarana i stoga što Moravska nije bila jezično jedinstvena: u njoj su obitavala slovačka, češka, lužičkosrpska i poljska plemena. Slično je bilo i u Panoniji, gdje se dodiruju zapadnoslavenski i južnoslavenski jezici. Pri stvaranju velikomoravske književne norme dolazi do simbioze južnoslavenskoga i zapadnoslavenskoga elementa, a na temelju takve osnove kasnije se stvara ohridska i preslavska književna norma. U Moravskoj i Panoniji ulaze u jezik mjesni elementi, tzv. moravizmi i panonizmi, od kojih su neki još prije Ćirila i Metoda ušli u crkvenu terminologiju zapadnih Slavena zajedno s germanizmima i latinizmima. ${ }^{5}$

Posebnu su pozornost istraživača starocrkvenoslavenskoga leksika privlačile riječi zapadnoga podrijetla za koje se pretpostavlja da su u tekstove ušle u Moravskoj i Panoniji. Sama moravska redakcija nije bila posve jedinstvena, tj. postojale su mnoge leksičke inačice. ${ }^{6}$ Za neke parove inačica nije lako odrediti koja je od njih starija, a koja mlađa. Primjerice, u paru propęti / raspęti prva je riječ prastara dubleta iz istočne Panonije, ali i srpska lokalna osobina, dok je druga češko-slovačka inačica, ali je svojstvena i slovenskomu i hrvatskomu te bugarskomu. Slično je i s parom prognêvati / razgnêvati. Panonski je dijalekt imao miješani karakter, sadržavao je južnoslavenske i zapadnoslavenske

\footnotetext{
2 PETROVIĆ 1988: 21.

3 ŠTEFANIĆ 1969: 15; HERCIGONJA 1975: 15-16; BIRNBAUM 1996.

4 Usp. HRISTOVA 2004; MIHALJEVIĆ; ŠIMIĆ 2013: 11-23; MIHALJEVIĆ 2018 (u tisku).

5 DESPODOVA 1993: 57.

6 STANKOV 2016: 135.
} 
jezične crte u leksiku. Mnoge izolekse posebice iz religijske ili kulturne terminologije bile su u 9.-10. stoljeću zajedničke hrvatskomu, srpskomu, slovenskomu i zapadnoslavenskomu jezičnom arealu. ${ }^{7}$

Pri analizi prvoga pisanog slavenskog jezika također treba uzeti u obzir njegovo kulturno-povijesno značenje i njegovu funkciju liturgijskoga jezika i jezika pismenosti. »Ujedno dolazi do izražaja specifičan karakter njegova leksičkoga i gramatičkoga sustava koji se razvijao u konfrontaciji s grčkim jezikom predložaka i ujedno u konfrontaciji s domaćim dijalektnim sustavima. Sve su te specifičnosti utjecale na oblikovanje autonomne strukture jezika za koju je karakteristična heterogena struktura leksičkoga sustava i visok stupanj varijabilnosti na svim razinama. $\ll^{8}$

Premda se oko kategorizacije pojedinih moravizama istraživači razilaze, ipak većina drži da su to sljedeći leksemi: bratrъ, buky, vъniti, godi$n a$, gradbcb, grobište, grozbnъ, drevlje, drъkolb, životъ, zaklěpati, znamenati, iskazati, kokošb, ladii, ladiica, misa, mrbziti, myto, nalęcati, napastb, neprijaznb, nebesbskъ, otъpustiti, otrokъ, pastyrb, prositi, pěnęzb, propęti, rěsnota, spyti, studenbcb, sъnьmъ, šjui, uměti, hrъbbtъ, cěsarbstvie, člověčbskъ, jędro... Ovdje je potreban poseban oprez kao i inače kad je riječ o leksiku pojedinih tekstova, ponajprije stoga što su riječi podrijetlom iz latinskoga jezika, npr. komkanie, mbša , vsemogi ${ }^{9}$ i sl. mogle ući u hrvatske tekstove izravno iz latinskoga, tj. riječ je o balkanskom latinitetu. ${ }^{10}$ Osim toga, novija su istraživanja pokazala da se pojedini leksemi ne mogu kategorizirati kao moravizmi jer su poznati i južnoslavenskim govorima. Tako, primjerice, premda je u tim istraživanjima Jagićev autoritet nenadmašiv, neki leksemi koje je on smatrao moravizmima danas to više nisu jer se često pojavljuju i u južnoslavenskim govorima: račiti, ašutı, ${ }^{11}$ balii, varovati se. Broj moravizama u literaturi varira od vremena do vremena, s obzirom na različite kriterije, tako se u novije vrijeme taj broj sveo na svega njih 18: balii, vêko, vbsemogy, gospoda, drıkolb, komъkanije, komъkati, malıžena, milosrbdije, mъnihъ, mьša, neprijaznb, olъtarb, papežb, rêsnota, rêsnotivъ, timêno, timênije. ${ }^{12}$ Važno je spomenuti da su pojedini moravizmi koji su u tekstove uneseni u Moravskoj kasnije prilagođeni južnoslavenskim govorima, npr.: nedêlja cvêtınaja termin

\footnotetext{
${ }^{7}$ STANKOV 2016: 135.

${ }^{8}$ RIBAROVA 2017: 84.

${ }^{9}$ Prema drugim mišljenjima vsemogi je možda kalk prema germanskomu.

${ }^{10}$ HCJ 2014: 384-385.

${ }^{11}$ RIBAROVA 2005a: 26.

12 HUŤANOVÁ 1998: 76-98; STANKOV 2016: 62.
} 
koji je najvjerojatnije nastao pod latinskim utjecajem, lat. dominica florum. ${ }^{13}$ Taj termin dobro je oprimjeren u liturgijskoj tradiciji južnih Slavena, kako pravoslavnih, tako i katolika, npr. u bugarskom, kao Cvetnica uz Vrbbnica, u srpskom: Cvetna nedelja ili Cveti u hrvatskom Cvjetnica, Cvijeti i Uličnica. ${ }^{14}$ U slavenskim kanonskim rukopisima nije potvrđen leksem cvêtbnica, nego samo nedêlja cvêtbnaê i to u Assemanijevu evanđelistaru i Savinoj knjizi. ${ }^{15}$

Metoda određivanja leksičkih moravizma prema Rostislavu Stankovu ima mnogo nedostataka i nije precizno utvrđena, čak ni Jagić nije utvrdio stroge principe za određivanje te leksičke kategorije. ${ }^{16}$ Jana Hut'janová navodi temeljne kriterije za utvrđivanje moravizama:

1. leksem se nalazi u kanonskim makedonsko-bugarskim tekstovima

2. genetski se veže za Veliku Moravsku i Panoniju

3. nema genetske sličnosti s južnoslavenskim jezicima

4. nalazi se u tekstovima moravsko-čeških prijevoda. ${ }^{17}$

Uz hrvatske crkvenoslavenske tekstove moravizmi su prisutni i u ruskim, češkim i bugarskim tekstovima, a posebice u makedonskim jer oni čuvaju tradiciju, tj. arhaičan prijevod. Zahvaljujući tome, može se rekonstruirati prvobitni slavenski tekst, odnosno zahvaljujući konzervativnosti ohridske književne škole u tim se rukopisima čuvaju pojedini arhaizmi: grecizmi, moravizmi i germanizmi. Tako su leksički moravizmi ušli u jezik makedonske srednjovjekovne pismenosti, a posebice se to odnosi na moravizme iz područja materijalne kulture, pravne terminologije i kršćanskih i crkvenih pojmova, npr.: olbtarb, olêi, ocbtı, vino, krbstı, ašutb, spyti, drъkolb, nebesbskъ, robъ, židı, zakonъ, papežb, napastınъ, neprijazninъ, izvolenie, naznamenovati, sъpasitelevъ, bližbnii, bližika, naslêdovati, kazati itd. ${ }^{18}$

\section{LEKSIK DRUGOGA BERAMSKOGA (LJUBLJANSKOGA) BREVIJARA}

Leksik Drugoga beramskoga (ljubljanskoga) brevijara $\left(\mathrm{BrLab}_{2}\right)$ je kao i leksik drugih hrvatskoglagoljskih liturgijskih rukopisa višeslojan, u njemu su nataloženi različiti stariji i mlađi leksički slojevi: staroslavenizmi, grecizmi,

\footnotetext{
${ }_{13}^{13}$ MAREŠ 1956: 259.

${ }^{14}$ MINČEVA 1999: 105 i 108.

15 MINČEVA 1999: 106.

${ }^{16}$ STANKOV 2016: 59.

${ }^{17}$ HUŤANOVÁ 1998: 57.

${ }^{18}$ DESPODOVA 1993: 58.
} 
latinizmi, moravizmi, ohridizmi, germanizmi i kroatizmi, tj. čakavizmi, koji svjedoče o različitim predlošcima naših rukopisa i različitim jezičnim utjecajima. Premda ovaj rukopis još uvijek nije posve potanko istražen i opisan, uočeno je da se na gotovo svim jezičnim razinama, fonološkoj, morfološkoj, sintaktičkoj prepleću sjeverne i južne karakteristike hrvatskoglagoljskih kodeksa. ${ }^{19}$ To je osobito izraženo na leksičkoj razini koja je najpodložnija promjenama. Uz prodor mlađih, dijalekatskih jezičnih inovacija, npr.: začb $\left(\mathrm{BrLab}_{2} 1 / 54 \mathrm{a}, 1 / 60 \mathrm{a}\right){ }^{20}{ }^{2} \check{c}\left(\operatorname{BrLab}_{2} 1 / 58 \mathrm{~b}\right)$, onom(a)dne (BrLab $\left.21 / 66 \mathrm{c}\right)$, počan'ši ( $\left.\mathrm{BrLab}_{2} 1 / 82 \mathrm{~d}, 1 / 93 \mathrm{~d}\right)$, začan'ši $\left(\mathrm{BrLab}_{2} 1 / 93 \mathrm{~b}, 1 / 93 \mathrm{c}\right)$, gredeši $(\mathrm{Br}-$ $\left.\mathrm{Lab}_{2} 2 / 104 \mathrm{~d}\right)$, ako (BrLab 2 2/107d), êli bi (BrLab 2 2/110c), počans ( $\mathrm{BrLab}_{2}$ 2/110d), betezi ( $\left.\mathrm{BrLab}_{2} 2 / 112 \mathrm{~d}\right)$, nikada $\left(\mathrm{BrLab}_{2} 2 / 121 \mathrm{~d}\right)$, on'di (BrLab 2 2/121d), $k(a) d a\left(B_{2 L a b} 2 / 85 \mathrm{c}\right.$ ), otb s(ve)tacb (BrLab 2/118b) (umj. otb blagdanb), opetb ( $\left.\mathrm{BrLab}_{2} 2 / 121 \mathrm{c}\right)$, svakako treba istaknuti ostatke staroga leksika koji ovaj rukopis povezuju s najstarijim slavenskima. To se odnosi primjerice na leksem Spasb umjesto Isusb koji se prilično često upotrebljava u ovom rukopisu: Spasb (BrLab 2 1/111b), $k$ spasu $\left(\right.$ BrLab $\left._{2} 1 / 118 b, 1 / 120 \mathrm{c}\right)$, spasb (BrLab 2 1/118d, 1/121d), Spasb (BrLab $21 / 183 b)$, sp(a)sa (BrLab 1/153a, 1/154b). Leksem Spas u značenju 'Spasitelj, Salvator' imaju crkvenoslavenski kanonski rukopisi, npr. Zografsko evanđelje, Savina knjiga, Suprasaljski zbornik itd., a od hrvatskoglagoljskih rukopisa potvrđen je u Vrbničkim fragmentima, 1. vrbničkom i Padovanskom brevijaru, 4. vatikanskom misalu, a u Lobkovicevu psaltiru nalazi se u Oficiju u čast sv. Trojice. ${ }^{21}$ Osim toga, važno je istaknuti da se u $\mathrm{BrLab}_{2}$ nalaze još neki arhaizmi, npr. grecizmi koji se vrlo rijetko pojavljuju u drugim hrvatskoglagoljskim rukopisima, npr.: akrogonb, u značenju 'ugaoni kamen', akrogon' (BrLab $\left.{ }_{2} 1 / 17 \mathrm{~b}\right)$, potvrđeno još jedino u najstarijem brevijaru, 1. vrbničkom $\left(\mathrm{BrVb}_{1} 19 \mathrm{c}\right)$ i Brevijaru Vida Omišljanina (BrVO 28d), antrakosb u značenju 'bdelij', an'trakosb $\left(\mathrm{BrLab}_{2} 1 / 92 \mathrm{~b}\right)$, i još samo u (BrVO 128a). Ovaj je rukopis iznimno zanimljiv i po tome što u njemu nalazimo veći broj leksema koji nisu potvrđeni u Rječniku crkvenoslavenskoga jezika hrvatske redakcije ili su potvrđeni vrlo malim brojem primjera. ${ }^{22}$ Neki od njih nisu zabilježene ni u starocrkvenoslavenskim rječnicima, npr.: hunusb u značenju tresak, prêavacb u značenju stomak itd. ${ }^{23}$

\footnotetext{
${ }^{19}$ MIHALJEVIĆ 2011: 126-139.

${ }^{20}$ Napomena broj 1 ili 2 ispred folijacije označava 1. ili 2. dio Drugoga beramskoga brevijara u kojem je leksem potvrđen.

${ }^{21}$ PANTELIĆ 2013: 515.

${ }^{22}$ MIHALJEVIĆ 2017: 53-59.

${ }^{23}$ MIHALJEVIĆ 2011: 136 i 137.
} 
Treba spomenuti da je u Drugom beramskom brevijaru iznimno često glosiranje, tj. prevođenje određenih leksema s hebrejskoga, grčkoga, latinskoga na hrvatski crkvenoslavenski jezik, odnosno navođenje sinonimskih parova. Glosiranje, uz kontekst i paralelne grčke ili latinske tekstove pomaže pri određivanju značenja staroslavenskih i crkvenoslavenskih tekstova, što je jedan je od najsloženijih problema lingvistike, a posebice kad je riječ o leksikalnoj semantici u povijesnoj perspektivi, jer se tad problemi višestruko umnažaju. Pri opisivanju značenja u leksikalno-povijesnoj semantici zapravo ne raspolažemo značenjem, poznat nam je samo znak, a značenje se mora odrediti. ${ }^{24}$ Primjeri: petrb že obraĉ' se kb serenu iže est' sl(o)vin 'ski vedar' vasb si ob'lbčen i i primračanb deli êv'laeši $\left(\mathrm{BrLab}_{2} 2 / 56 \mathrm{~d}\right), d a z v(a) l$ se bi sa d(a)nb efifanie eže latin'ski êv'lenie reĉi možet se (BrLab $1 / 57 \mathrm{c})$, mučenik' bo latin'ski g(lago)let' se svêdokb ( $\left.\mathrm{BrLab}_{2} 2 / 108 \mathrm{c}\right)$, kriz'me že milosti latin'ski pomazanie imenuet'se $\left(\mathrm{BrLab}_{2} 1 / 121 \mathrm{~b}\right)$, emanuelb iže estb $s$ $n(a) m i b(o g) b\left(B_{b L a b} 2 / 122 b\right)$, bartolomei ap(usto)lb ime ot surêisk(a)go êzika priêmb tl'kuet se s(i)nb viš(a) ûc(a)go ( $\left.\mathrm{BrLab}_{2} 2 / 125 \mathrm{a}\right)$, viste êk(o) rav'vi moistarb e(stb) (BrLab $\left.{ }_{2} 1 / 125 \mathrm{c}\right)$, evreiski i(su)sb latin'ski sal'vatorb grčbski šotorb sl(o)vinski že sp(a)sit(e)lb g(lago)letb se (BrLab 2 2/159d/160a), ime eтu ev'reiski lav'daons grčki apolions latin'ski ispruždaei $\left(\mathrm{BrLab}_{2} 1 / 174 \mathrm{c}\right)$, ime emu evreiski adoutukas (!) grčki paraklitb latin'ski kon'sulatorb slovin 'ski utišitelb tlkuetb se (BrLab $\left.{ }_{2} 1 / 193 \mathrm{c}\right)$ itd.

\section{MORAVIZMI U DRUGOM BERAMSKOM (LJUBLJANSKOM) BREVIJARU}

Potencijalne panonizme/moravizme u hrvatskoglagoljskim tekstovima možemo, slično kao i preslavizme podijeliti u dvije skupine. Prvu skupinu čine riječi koje nisu hrvatske, a ne mogu se prema dosadašnjim spoznajama promatrati ni kao preslavizmi niti kao ohridizmi. Drugim riječima, to su sigurni moravizmi, neovisno o kontekstu.

Primjeri iz Drugoga beramskoga (ljubljanskoga) brevijara:

- balii 'vrač': balii (BrLab 2 2/8a), balovanie 'liječenje, izlječenje': bblovanie (BrLab 2 2/39c), balstvo 'liječenje, izlječenje': bal'stva $\left(\mathrm{BrLab}_{2}\right.$ $1 / 136 \mathrm{c})$;

- varovati 'čuvati, paziti': varoval' (BrLab 2 2/155d) jednokratnica u $\mathrm{BrLab}_{2}$;

$\overline{{ }^{24} \text { MARTI 1994: } 23 .}$ 
- vsemogi 'svemoguć': v'semoguĉumu (BrLab 2 2/83c), vsemoguĉega (BrLab $21 / 259 \mathrm{c}, 2 / 28 \mathrm{~d})$, vbsemogi (BrLab $\left.{ }_{2} 1 / 74 \mathrm{~d}, 2 / 14 \mathrm{a}\right)$, v'semogi $\left(\right.$ BrLab $\left._{2} 1 / 47 \mathrm{c}, 1 / 133 \mathrm{a}, 1 / 136 \mathrm{c}, 2 / 26 \mathrm{a}, 2 / 52 \mathrm{~d}\right)$, učestalo se pojavljuje u rukopisu;

- dreselb 'tužan, žalostan': dreselu (BrLab 2 2/124c), dreselb $\left(\mathrm{BrLab}_{2}\right.$ 2/103b), dreseliti 'zbunjivati, žalostiti': dreseletb (BrLab 2 2/91d);

- drbkola 'palica': pojavljuje se samo u dva primjera i to u 1 . dijelu brevijara: dr'kolami (BrLab 2 149b, 152d) ${ }^{25}$;

- drêvle 'davno': drêvlb, tj. drevlee (BrLab 2 1/199d), u rukopisu nije potvrđen leksem kao prilog, veznik ili prijedlog kao u Rječniku, nego samo kao pridjev;

- nedugb 'bolest, nemoć, slabost': nedugom' (BrLab 2 2/10d), neduzi ( BrLab $_{2} 2 / 114 \mathrm{a}$, neduga ( BrLab $\left._{2} 2 / 156 \mathrm{c}\right)$, nedugi $\left(\mathrm{BrLab}_{2} 1 / 7 \mathrm{c}\right)$;

- nepriêznь 'zlo, đavo, zloduh' je u $\mathrm{BrLab}_{2}$ potvrđeno s tri leksema: nepriêzanb: nepriêz'ni (BrLab $21 / 1196 \mathrm{c})$, nepriêz'niû ( $\left.\mathrm{BrLab}_{2} 1 / 186 \mathrm{c}\right)$, nepriêzninb: nepriêz'nihs ( $\left.\mathrm{BrLab}_{2} 2 / 1 \mathrm{~d}\right)$, nepriêz'nivb: nepriêznivimb $\left(\mathrm{BrLab}_{2} 1 / 116 \mathrm{a}\right){ }^{26}$

- otrokb 'dijete, dječak', otrokovica 'djevojčica': ot'roče (BrLab $2 / 74 \mathrm{~d})$, otrok ( BrLab $\left._{2} 2 / 72 \mathrm{c}\right)$, otrokoma $\left(\mathrm{BrLab}_{2} 1 / 100 \mathrm{c}\right)$, otrokovici $\left(\mathrm{BrLab}_{2}\right.$ 1/28c), ot'rokovicu (BrLab 2 1/243c);

- rêsnota ${ }^{27}$ 'istina': od korijena rêsn- tvorena su četiri leksema, najčešći je rêsnota, npr.: res'nota $\left(\mathrm{BrLab}_{2} 2 / 67 \mathrm{~d}\right)$, resnoti $\left(\mathrm{BrLab}_{2} 1 / 113 \mathrm{a}\right.$, BrLab $_{2} 1 / 145 b$, BrLab 2 2/15d, BrLab 2 2/17b), rêsnotê (BrLab 2 1/237b), res'notu $\left(\mathrm{BrLab}_{2} 1 / 100 \mathrm{~b}\right)$, dva priloga rêsnê: rêsne $\left(\mathrm{BrLab}_{2} 2 / 106 \mathrm{a}\right) \mathrm{i}$ rêsno: res'no (BrLab $\left.{ }_{2} 1 / 98 \mathrm{a}\right)$ i pridjev rêsnotivanb: resnotiv'ni $\left(\mathrm{BrLab}_{2}\right.$ $1 / 103 \mathrm{c})^{28}$

${ }^{25}$ U drugim se hrvatskoglagoljskim rukopisima drbkola za 'palica, batina, štap, kolac' pojavljuje u biblijskim tekstovima, npr. u Muci po Marku i Mateju: êko na razboinika li izidote na me sb oružiem ' is dr 'kolami êti me $\mathrm{MVat}_{4} 80 \mathrm{~b}$ (Mk 14,48), pride i s nim' narod' mnog' sb oružiem' is dr'kolami MVat ${ }_{4} 74 \mathrm{~d}$ (Mt 26,47).

${ }^{26}$ Prema novijim istraživanjima leksem nepriêzn je nastao pod utjecajem balkanskoga latiniteta, što potvrđuje njegova učestalost u tekstovima makedonske i hrvatske redakcije (RIBAROVA 2005.b: 370).

${ }^{27}$ Većina slavista koji su se bavili moravizmima smatra da je rêsnota unesena u Moravskoj, počevši od Jagića do Lbvova koji drži da su riječi s korijenom rêsn- u 9. i 10. stoljeću postojale u sjeverozapadnom dijelu južnoslavenskoga područja i ušle u staroslavenski jezik kao uzus (STANKOV 2016: 64-65).

${ }^{28}$ Moravizam rêsnota se za razliku od hrvatskoglagoljskih tekstova, rijetko pojavljuje u makedonskim crkvenoslavenskim tekstovima (RIBAROVA 2010: 110). 
- šui 'lijevi': šuimb (BrLab $\left.{ }_{2} 1 / 103 \mathrm{c}\right)$, šuihs (BrLab $\left.{ }_{2} 1 / 13 \mathrm{~b}\right), \check{s} u \hat{u}\left(\mathrm{BrLab}_{2}\right.$ 1/105d); šuica 'ljevica': šuicu (BrLab 2/11c, 2/12a). Valja napomenuti da se u Drugom beramskom (ljubljanskom) brevijaru šui pojavljuje češće nego lêvb i to uglavnom u prvom dijelu rukopisa.

U drugoj su skupini riječi koje su svojstvene i hrvatskim govorima. One se ne mogu smatrati moravizmima neovisno o kontekstu, već samo u pojedinom značenju;

- velmi 'vrlo, veoma, jako': u BrLab 2 se pojavljuje vrlo često kako u 1. tako i u 2. dijelu rukopisa, za razliku od starijega zêlo koje je znatno rjeđe, tj. u omjeru 112: 38, npr.: vêl'mi (BrLab $2 / 116 \mathrm{a}, 1 / 159 \mathrm{~d}, 1 / 161 \mathrm{c})$, velbmi $\left(\right.$ BrLab $_{2} 1 / 41 \mathrm{~b}$, BrLab $_{2}$ 1/210a) itd. ${ }^{29}$

- voinb 'vojnik, ratnik': također se iznimno često nalazi u BrLab 2 kako u prvom tako i u drugom dijelu brevijara, npr.: voina $\left(\right.$ BrLab $_{2} 2 / 83 \mathrm{a}$, 2/104b), voin' (BrLab 2 2/144a), vojin ( BrLab $\left._{2} 2 / 61 \mathrm{a}\right)$ itd. Od ovog su korijena tvoreno još četiri leksema: voinstvovati $\left(\mathrm{BrLab}_{2} 2 / 61 \mathrm{a}\right)$, voinstvo, voinstvomb ( $\left.\mathrm{BrLab}_{2} 2 / 92 \mathrm{~b}\right)$, voinstvie, voin'stviemb $\left(\mathrm{BrLab}_{2}\right.$ 2/40b), voinskb, voin'skihb (BrLab 2 1/174d);

- včeti 'početi': također često u rukopisu, npr.: vač'nêši ( BrLab $\left._{2} 2 / 130 b\right)$, vačbnetb ( $\left.\mathrm{BrLab}_{2} 2 / 18 \mathrm{~b}\right)$, vač'niši ( $\left.\mathrm{BrLab}_{2} 2 / 106 \mathrm{~b}\right)$, vačn(u)tb ( $\mathrm{BrLab}_{2}$ 1/59d), vač'nutb (BrLab $21 / 4 \mathrm{~b}, 1 / 5 \mathrm{~d}, 1 / 6 \mathrm{~d}, 2 / 38 \mathrm{~b}, 2 / 39 \mathrm{~b})$;

- mito 'mito': mitomb (BrLab 2 2/93c), mita (BrLab 2 1/106a);

- mrbzêti 'mrziti': korijen mrbz- oprimjeren je sa šest različitih leksema: omrbznuti: omr'znuv'še (BrLab 2 2/28d), mrbzakb: mrski (BrLab 2/23d), mrbzêti: mrzecii (BrLab 2/89b), mrbzostb: mrzostiû (BrLab 1/110c), bogomrbzacb: bogomr'sci (BrLab 2 1/71c), mrbzovanie: mr'zovanie (BrLab 2 1/2b);

- pastirb 'pastir': potvrđena su četiri leksema:pastirb:pastiru $\left(\mathrm{BrLab}_{2} 2 / 20 \mathrm{a}\right.$, 2/27d, 2/162c), pastirevb: pastirevomb (BrLab 2 1/218d), pastirskb: pastir'skihь (BrLab 2 2/129d), i jednokratnica stražpastirb: stražıpastirb $\left(\right.$ BrLab $\left._{2} 1 / 45 \mathrm{c}\right)$ koja u Slovníku nije posvjedočena, a u građi za Rječnik

${ }^{29}$ Leksem velbmi unesen je u slavenske tekstove u Moravskoj, što potvrđuje činjenica da je u tekstovima moravsko-češkoga područja pretežno velbmi, primjerice u ŽM, dok je u južnoslavenskom dijalektu, na koji su prevedene prve slavenske knjige, bilo zêlo i zêlo. Leksem velbmi je u Sinajski psaltir unesen u Moravskoj isto kao i rêsnota, ondje je potvrđeno 29 puta zêlo i zêlo, a samo dva puta velbmi. Pri tome je zanimljivo da se velbmi pojavljuje pri kraju psaltira, tj. u Ps 118,51 i Ps 118,107. Potrebno je istaknuti da se hrvatskoglagoljski psaltiri u potpunosti slažu sa Sin, tj. uvijek imaju zêlo ili zelo, npr. Ps 6,$4 ; 6,11 ; 20,2 ; 30,12 ; 36,23$; 37,9; 45,2 itd., dok u Ps 118,51 i 118,107 imaju velbmi. 
samo na jednom mjestu u sljedećim rukopisima: stražbpbstir' (BrVO 58a), stražbpastirb ( BrVat $\left._{5} 33 \mathrm{~b}, \mathrm{~N}_{2} 34 \mathrm{a}, \mathrm{Pm} 34 \mathrm{c}\right)$;

- prisno 'uvijek, neprestano, vječno': u BrLab ${ }_{2}$ posvjedočen je prilog u nekoliko slučajeva, npr.: pris'no (BrLab 2 1/103d 1/105b, 1/125c, 2/28a, 2/94d, 2/157b) i imenica prisnota kao jednokratnica ( BrLab $\left._{2} 1 / 78 \mathrm{~b}\right)$;

- propeti 'propeti, raspeti': propete $\left(\mathrm{BrLab}_{2} 2 / 108 \mathrm{~d}\right)$, propetago $\left(\mathrm{BrLab}_{2}\right.$ 1/159d, BrLab 2 2/111d) (često);

- prositi 'prositi': u rukopisu su četiri leksema: prositi: prošahu $\left(\mathrm{BrLab}_{2}\right.$ 2/126b), vsprositi: v'sprošu ( $\left.\mathrm{BrLab}_{2} 2 / 127 \mathrm{c}\right)$, isprositi: is 'prošena $(\mathrm{Br}-$ $\left.\mathrm{Lab}_{2} 2 / 51 \mathrm{c}\right)$, uprositi: uprošenb $\left(\mathrm{BrLab}_{2} 1 / 125 \mathrm{~d}\right)$ (često);

- pênezb 'novac': pinêzemb ( $\left.\mathrm{BrLab}_{2} 2 / 38 \mathrm{c}\right)$, pinez' $\left(\mathrm{BrLab}_{2} 2 / 38 \mathrm{~b}\right)$, pênezi $\left(\mathrm{BrLab}_{2} 1 / 155 \mathrm{c}\right.$ (nije često);

- račiti 'udostojati, htjeti, željeti': često se nalazi u rukopisu, npr.: račil (BrLab $21 / 123 \mathrm{c})$, račil' (BrLab $21 / 39 \mathrm{~d})$, račilb $\left(\mathrm{BrLab}_{2}\right.$ 1/12a, 1/27b) itd.;

- sanmb 'skup, sabor': san'mi (BrLab $1 / 2 b)$, sanamnica: sanamnice ( $\left.\mathrm{BrLab}_{2} 2 / 129 \mathrm{c}\right)$, sanmiĉe: san 'miĉemb ( $\left.\mathrm{BrLab}_{2} 2 / 16 \mathrm{~b}\right)$;

- studenacb 'zdenac': studenbci (BrLab $2 / 77 \mathrm{~b})$, s'tuden'ci (BrLab 1/120d), studen'ca (BrLab $21 / 233 \mathrm{~b}, 2 / 10 \mathrm{~b}$ ) (rijetko);

- ubogb 'siromašan': ubogomu (BrLab 2 2/112b), uboga (BrLab 2 2/151d), ubogihb ( $\mathrm{BrLab}_{2}$ 1/14b, 82c, 2/107d).

Prema Milanu Mihaljeviću, kad je riječ o leksemima zapadnoga porijekla u najstarijim hrvatskoglagoljskim fragmentima nalazimo tri skupine:

1. oni koji su u Slovníku potvrđeni malim brojem primjera, a mogu se smatrati kroatizmima ili eventualno moravizmima sačuvanima samo u hrvatskoglagoljskim rukopisima. I u Drugom beramskom brevijaru su također potvrđeni skoro svi (osim vladatelb), npr.: vihititi: vihitils (BrLab 2 2/166a), vihiceni (BrLab 2 1/80c), imna: imni (BrLab 2 2/118c), križb: kr(i)̌̌b ( $\left.\mathrm{BrLab}_{2} 2 / 189 \mathrm{~d}\right)$, križanb: k'riž'nimb ( $\left.\mathrm{BrLab}_{2} 1 / 39 \mathrm{a}\right)$, lêki: (BrLab ${ }_{2}$ liki 2/121c), matutinb: m(a)t(ut)i(nê) (BrLab 2 1/73b), misa: misi (BrLab 2 1/33c, 1/50d), maša: maši ( $\left.\mathrm{BrLab}_{2} 1 / 205 \mathrm{a}\right)$, nepriêtelь: nepriêtelû ( $\left.\mathrm{BrLab}_{2} 2 / 75 \mathrm{~d}\right)$, obakb: obsk' ( $\left.\mathrm{BrLab}_{2} 1 / 59 \mathrm{a}\right)$, obênčati: obên'čaeši ( $\left.\mathrm{BrLab}_{2} 2 / 132 \mathrm{c}\right)$, omiliê: omiliû ( $\left.\mathrm{BrLab}_{2} 1 / 243 \mathrm{~b}\right)$, prozba: prozbami ( $\left.\mathrm{BrLab}_{2} 2 / 142 \mathrm{c}\right)$ itd.

2. Leksemi potvrđeni u Slovníku u tekstovima zapadnoga podrijetla, a dobro oprimjereni u Rječniku, mogu se smatrati zapadnim elementima, moravizmima/panonizmima ili kroatizmima, većina njih potvrđena je i u Drugom beramskom brevijaru, (osim batogb, milo- 
stivno, nositelb, ohopiti, ptičb, rodstvie): balovanie: bblovanie ( $\mathrm{Br}-$ $\left.\mathrm{Lab}_{2} 2 / 39 \mathrm{c}\right)$, viiti: višadbšiê $\left(\mathrm{BrLab}_{2} 2 / 131 \mathrm{c}\right)$, vêcnica: viĉ'nicu (Br$\left.\mathrm{Lab}_{2} 2 / 23 \mathrm{~d}\right)$, isprostrêti: is 'prostriše ( $\left.\mathrm{BrLab}_{2} 2 / 82 \mathrm{~d}\right)$, krêpcê: krêp'ce (BrLab 2 2/144d), lakomostb: lakomosti (BrLab $21 / 224 b)$, nastoênie: nas'toêniem' ( $\left.\mathrm{BrLab}_{2} 2 / 159 \mathrm{~b}\right)$, obêtanb: obet'nimb ( $\left.\mathrm{BrLab}_{2} 2 / 31 \mathrm{a}\right)$, požidanie: požidaniems ( $\left.\mathrm{BrLab}_{2} 1 / 26 \mathrm{a}\right)$, raždaliti se: raz'žali $\left(\mathrm{BrLab}_{2}\right.$ $1 / 258 \mathrm{~d})$, raspačati se: ras'pačaemb $\left(\right.$ BrLab $\left._{2} 2 / 31 \mathrm{a}\right)$ itd.

3. Leksemi iz fragmenata koji su u Slovníku potvrđeni samo s jednim ili dvama primjerima iz najstarijih tekstova (Ev, Euh, Psalt, Apost), oni su u starocrkvenoslavenskom arhaizmi, najčešće zapadnoga porijekla, a u hrvatskoglagoljskim tekstovima nisu arhaizmi. Dijele se u dvije skupine: oni koji u Rječniku imaju puno primjera i svi su potvrđeni u Drugom beramskom brevijaru, osim leksema korito, npr.: bedra: bedri ( BrLab $\left._{2} 2 / 132 \mathrm{a}\right)$, dažditi: daždi ( BrLab $\left._{2} 1 / 202 \mathrm{~d}\right)$, zaĉititelb: zacititela (BrLab 2 2/87d), zaĉicati: zaĉiĉaeši ( BrLab $\left._{2} 2 / 82 \mathrm{~b}\right)$, ledina: ledinê ( $\left.\mathrm{BrLab}_{2} 1 / 24 \mathrm{~b}\right)$, itd. i oni koji u Rječniku imaju malo primjera (uglavnom zastarjelice ili posuđenice iz drugih redakcija), a koje u Drugom beramskom brevijaru nisu posvjedočene, osim: nakoliti: nakolih' (BrLab $\left.{ }_{2} 1 / 24 \mathrm{a}\right)$, netlêe: net'lêûcago (BrLab 2 1/71a) i potrêblenie: potrêblenie ( BrLab $_{2}$ 1/245d). Sve spomenute leksičke kategorije iz najstarijih hrvatskoglagoljskih fragmenata potvrđuju ponajprije da je leksik Drugoga beramskoga brevijara prilično arhaičan, a zatim i da je znatan dio leksema u tom rukopisu zapadnoga porijekla.

Na kraju treba spomenuti neke riječi koje se u literaturi navode kao moravizmi, a ne pojavljuju se u Drugom beramskom brevijaru:

- vsudb 'pričest' među hrvatskoglagoljskim rukopisima leksem je potvrđen u najstarijim fragmentima: vbsuda (FgVind 2a), vsudb (FgEust 1a), ${ }^{30}$

- ešutb 'bez razloga, uzalud'. U drugim se hrvatskoglagoljskim rukopisima ovaj leksem pojavljuje kao prilog, imenica ili pridjev, ešutınb, većinom u biblijskim tekstovima, najčešće u Propovjedniku i Psaltiru. Važno je napomenuti da se neki moravizmi u BrLab $_{2}$ ne pojavljuju posve slučajno, tj. zbog sadržaja teksta;

- komkanie, u našoj je građi leksem kombkanie potvrđen samo u popričesnoj molitvi na dan sv. Ambrozija (7. 12.) u Splitskom fragmentu misala s početka 13. st. u obliku komъkan[i]e (a), u Berlinskom misalu iz 1402. u obliku kom 'kanie (157b), vatikanskom misalu Illirico 8 iz 1435. godine (233a), u istom obliku kao u Berlinskom misalu, te

$\overline{{ }^{30} \text { RCJHJ 2015: } 64 .}$ 
u Newyorškom misalu iz sredine 15. st. (205c) gdje je sintagma see ni kombkanie krivo rastavljena kao see niko mbnkanie;

- ladii, ladiica, u hrvatskoglagoljskim rukopisima nalazi se npr. u Brevijaru Vida Omišljanina, ladi (139c), 2. novljanskom brevijaru: v' ladiû (388a/b), 1. beramskom (ljubljanskom) brevijaru: v' lad'û (11b), uz sinonim korabl' npr. u 1. vrbničkom brevijaru (93d), korabalb 2. novljanskom brevijaru (65c) itd.;

- malženica, malženstvo, malžena, malženstvo nije potvrđeno u $\mathrm{BrLab}_{2}$, dok se nalazi u drugim hrvatskoglagoljskim rukopisima, npr. u Fragmentu apostola o malženstvê (FgApost 2d), u Akademijinu ritualu (RitAc 9v): Prizri m(o)l(i)m te g(ospod)i sb n(e)b(e)se s(ve)t(a)go tvoego nb siê mal'nêža ..., u Grškovićevu zborniku (CGrš 148r): o gore tima malženoma ka oskvrnista lože svoe;

- malomoĉb, potvrđeno u najstarijim hrvatskoglagoljskim fragmentima, npr. u Krčkom fragmentu pasionala iz 13. st: $i$ abie [...] že nošaše zlato ra[...]aê malomoĉemb.

\section{ZAPADNOSLAVENSKI UTJECAJ U TVORBI RIJEČI}

Osim leksičkih zapadnoslavenizama u hrvatskoglagoljskim su tekstovima potvrđene neke osobitosti u tvorbi riječi koje bi mogle biti plod zapadnih utjecaja, ponajprije to je prefiks $v y$ - ${ }^{31}$ Međutim ne smijemo zaboraviti da je to sve do početka 20. stoljeća bila i osobina sjevernočakavskih govora. U Rječničkoj je građi taj prefiks potvrđen s 32 glagola, a i u Drugom beramskom brevijaru također je dobro oprimjeren $\mathrm{tj}$. sa 17 različitih leksema, npr.: vivesti: vivede (1/230c), vipiti: vipi (1/36d, 1/40c), vipluti: viplu (1/193a), viprostrêti: viprostiraše (2/158b), vipuĉati: vipuĉatb (1/215), vistati: vis'ta (2/89), vistupati: vistupaûĉ (2/1c), vistupiti: vistupi (1/17a, 2/21a), vitrgnuti: vitrg'nut' (1/23b), vihititi: vihitils (2/166a), vihoditi: vihoditb (1/78d) itd.

Riječi sa sufiksom -bskъ umjesto -bnъ su također zapadnoslavenski utjecaj, tako je primjerice oblik nebesbskb unesen u Moravskoj kako imaju četveroevanđelja Marijinsko i Zografsko, kao i Kijevski listići i Kločev glagoljaš. U Sinajskom, Pogodinskom i Bolonjskom psaltiru prednost imaju oblici zemьnъ, zemlınъ. U Sinajskom je psaltiru redovito nebesbnъ, dok je u hrvatskoglagoljskim psaltirima redovito neb(e)skb: (Ps 8,9; 49,11; 67,15; 77,24; $78,2 ; 90,1 ; 102,11 ; 103,12 ; 104,40 ; 135,26)$. U građi je rjeđi oblik nebesbn koji je zabilježen samo u Brevijaru Vida Omišljanina u primjeru nebesnû (BrVO 377b) te u Mihanovićevu fragmentu apostola: neb(e)sbna (FgMih 1d),

${ }^{31}$ HUŤANOVÁ 1998: 69. 
nebe[sbni]imb (FgMih 1d), n(e)bessnimb (FgMih 2b), nebesnihb (FgMih 2d). Nasuprot tomu, oblik nebeskb učestalo se pojavljuje u svim spomenicima: neb(e)skoe (FgSpal c), n(e)b(e)ski (MVat $\left.{ }_{4} 28 \mathrm{a}\right), n(e) b(e) s k o$ (BrVO 368d), $n(e) b(e) s k i\left(\mathrm{BrN}_{2} 364 \mathrm{a}, 445 \mathrm{a}\right), n(e) b(e) s k i\left(\mathrm{BrLab}_{1}\right.$ 175c) itd. I u BrLab ${ }_{2}$ redovito je zapadna varijanta nebeskb, npr.: neb(e)sk(i)mb (BrLab 2/111a), neb(e)skô̂ ( $\left.\mathrm{BrLab}_{2} 2 / 147 \mathrm{~d}\right)$, neb(e)skie ( $\left.\mathrm{BrLab}_{2} 2 / 146 \mathrm{a}, 2 / 129 \mathrm{~b}\right)$ itd., dok nebesnb nije potvrđeno.

Slično je i s varijantom človêčaskb koja je uobičajena u Drugom beramskom brevijaru, dok se človêčb pojavljuje samo jednom (BrLab $21 / 84 \mathrm{a})$. Za razliku od toga u rukopisu se uz češće zemalskb, npr.: z(e)m(a)lskimi (BrLab 2/21c), z(e)m(a)lskoû (BrLab 2 2/78d), zemalska (BrLab 2 2/152b), zemal'skihb (BrLab $21 / 93 \mathrm{a})$ pojavljuje i zemlanb: zem'lnaê $\left(\mathrm{BrLab}_{2} 1 / 31 \mathrm{~d}\right)$, zemlnimb (BrLab 2 1/189a, 2/169d), z(e)m(a)lnago (BrLab $21 / 33 b), 1 / 178 \mathrm{a})$.

Imenice sa sufiksom -ije, kojih je u starocrkvenoslavenskom jeziku preko 900, također su plod zapadnoslavenskoga utjecaja. U našoj je građi velik broj tih imenica, npr. bezlobie - bezlobiem' (PsFr 3b), bratolûbie - bratolûbie (BrVO 286c), bratolûbiem' (MVat ${ }_{4}$ 18b, Nov 20a, Roč 15b), bespametie - bes'pametiemb (BrVat ${ }_{5} 229 \mathrm{c}$ ) - hapax legomenon, bezgodie $-v$ bezgodi (PsLob 81r, Par 74r, BrAc 30a), blagoredie - bl(a)goredie (MVat ${ }_{4}$ 195b, Nov 205c, Roč 163c), bestudie - bestudie (FgLab $\left.{ }_{2} 1 \mathrm{a}\right)$ - hapax, bezumie - bezumie (FgSpal b, MVat ${ }_{4}$ 250c, BrVat 5 59c) itd., blagouhanie - blagouhanie (MVat 149d), bl(a)gouhanie (BrLab 1 154d), balovanie - balovaniû (MVat ${ }_{4}$ 131b), balovaniê (BrVO 250c, MVat 4 111b), bêsovanie - bêsov(a)niê $\left(\mathrm{BrN}_{2} 490 \mathrm{c}\right)$. U Drugom beramskom brevijaru je također velik broj tih imenica, npr.: balovanie - balovaniê (BrLab $1 / 36 \mathrm{~d})$, bezumie - bezumiê $\left(\mathrm{BrLab}_{2} 1 / 12 \mathrm{~b}, 1 / 119 \mathrm{c}\right.$, 1/235b, 2/67a, 2/83b), bezumiû (BrLab 2 1/235b), blagoredie - blagoredie (Br$\left.\mathrm{Lab}_{2} 1 / 182 \mathrm{~b}\right)$, blagouhanie - blagouhaniemb $\left(\right.$ BrLab $\left._{2} 2 / 12 \mathrm{~d}, 2 / 53 \mathrm{c}, 2 / 68 \mathrm{a}\right)$, blagouhaniê ( $\left.\mathrm{BrLab}_{2} 2 / 60 \mathrm{~b}\right)$, blagouhanie ( $\left.\mathrm{BrLab}_{2} 1 / 87 \mathrm{a}, 2 / 121 \mathrm{~d}\right)$, varovanie - varovaniê ( $\left.\mathrm{BrLab}_{2} 2 / 85 \mathrm{a}\right)$, gnêvanie - gnêvaniê ( $\left.\mathrm{BrLab}_{2} 2 / 26 \mathrm{~b}\right)$, darovanie darovaniems $\left(\mathrm{BrLab}_{2} 2 / 162 \mathrm{~d}\right)$, nepcevanie - nepcevaniê $\left(\mathrm{BrLab}_{2} 1 / 170 \mathrm{c}\right)$, plavanie - plavaniems ( $\left.\mathrm{BrLab}_{2} 1 / 225 \mathrm{~d}\right)$, počivanie - počivaniê $\left(\mathrm{BrLab}_{2} 1 / 187 \mathrm{~b}\right)$, sêtovanie - sêtovaniê (BrLab $2 / 163 \mathrm{~b})$, upvanie - ufaniems ( $\mathrm{BrLab}_{2} 2 / 34 \mathrm{~d}$, 2/161a), upvanie ( $\left.\mathrm{BrLab}_{2} 1 / 111 \mathrm{c}, 1 / 158 \mathrm{a}, 2 / 106 \mathrm{a}\right)$, čudovanie - čudovaniemb $\left(\mathrm{BrLab}_{2} 2 / 98 \mathrm{c}\right)$, čudovanii $\left(\mathrm{BrLab}_{2} 2 / 99 \mathrm{~b}\right)$.

\section{ZAKLJUČAK}

Ranija su istraživanja pokazala da su potencijalni moravizmi u hrvatskoglagoljskim tekstovima razmjerno brojni. Na temelju njihove razdiobe mogu se izvući zanimljivi zaključci kako o tekstovima tako i o njihovu podrijetlu. 
Kad je riječ o liturgijskim tekstovima, pokazalo se da je velika koncentracija moravizama u psaltiru i u evanđeljima. U osnovi je tih tekstova ćirilometodski prijevod koji su kasnije hrvatski glagoljaši u više navrata prilagođivali latinskomu tekstu Vulgate. To bi pak mogao biti pokazatelj da su ti tekstovi u Hrvatsku stigli sa sjevera, izravno iz Moravske i Panonije. Kako u Drugom beramskom brevijaru psaltir kao zasebna liturgijska knjiga nije očuvan, to je nemoguće provjeriti. U Drugom beramskom brevijaru neki su moravizmi uobičajeni i pojavljuju se jedino u toj inačici, nebeskb, drugi se pojavljuju paralelno uz južne varijante, velmi / zêlo, životb / žitie / žiznb, edinb / eterb, napastb / iskušenie, nedugb / bolêznb, rêsnota / istina, šui / lêvb, sanmb / zborb, dok neki nisu potvrđeni, npr.: buki, grobište, malžena, muditi, nalecati, natruti itd.

Ovu iznimnu kompleksnu problematiku predočit ću u nekim statističkim podacima, npr.: velmi se u brevijaru pojavljuje sveukupno 112 puta, a zêlo 38 puta, što potvrđuje da u ovom rukopisu prevladava moravska varijanta. Kad je riječ o sinonimima mito / mazda u BrLab 2 preteže južnoslavenska inačica mazda sa 69 primjera, dok se mito pojavljuje u 3 slučaja. Moravska varijanta sanamb i sanmice pojavljuje se češće u odnosu na zborb i zboricee, tj. $27: 12$ puta. Moravske su varijante šui i šuica češće nego lêvb, tj. $16: 6$. Nedugb se pojavljuje u 13 primjera, a bolêzno i bolêznivb u 45 primjera. Mogući moravizam rêsnota i rêsnotivanb se pojavljuje u 58 slučajeva, dok se istina i istinanb pojavljuje čak u 200 primjera.

U vezi sa zapadnoslavenskim utjecajem na leksičkoj razini nisu zamijećene neke značajnije razlike između prvog i drugog dijela brevijara, one mogu biti donekle uvjetovane sadržajem tekstova u pojedinim dijelovima rukopisa.

\section{IZVORI}

\section{KRATICE HRVATSKOGLAGOLJSKIH RUKOPISA}

BrAc $=$ Akademijin brevijar, oko 1384., Zagreb, Hrvatska akademija znanosti i umjetnosti, sign. III c 12 .

BrLab $_{1}=1$. beramski (ljubljanski) brevijar, kraj 14. st., Ljubljana, Narodna in univerzitetna knjižnica, sign. Ms 161.

$\mathrm{BrLab}_{2}=2$. beramski (ljubljanski) brevijar, 15. st., Ljubljana, Narodna in univerzitetna knjižnica, sign. Ms 163.

$\mathrm{BrN}_{2}=2$. novljanski brevijar, 1495., Novi Vinodolski, Župni ured.

BrVat $_{5}=5$. vatikanski brevijar, sredina 14. st., Rim, Biblioteca Apostolica Vaticana, sign. Borg illir. 5.

BrVO = Brevijar Vida Omišljanina, 1396., Beč, Österreichische Nationalbibliothek, sign. Cod. slav. 3. 
FgApost $=$ Fragment apostola, kraj 14. st., Zagreb, Hrvatska akademija znanosti i umjetnosti, sign. Fragm. glag. 54.

FgEust = Odlomak legende o svetom Eustahiju, početak 14. st., Zagreb, Hrvatska akademija znanosti i umjetnosti, sign. Fragm. glag. 90.

FgMih $=$ Mihanovićev fragment apostola, 12. st., Zagreb, Hrvatska akademija znanosti i umjetnosti, sign. Fragm. glag. 1.

FgSpal = Splitski fragment misala, početak 13. st., Split, Kaptolski arhiv, sign. 468.

FgLab $_{2}=$ Fragment homilije, prva pol. 14. st., Ljubljana, Narodna in univerzitetna knjižnica, sign. Glagolitica 16/I Gč 48. Fg. glag. hom.

FgVind = Bečki listići, 11. st., Beč, Österreichische Nationalbibliothek (ÖNB), sign. Cod. Slav. 136.

$\mathrm{MVat}_{4}=4$. vatikanski misal, najstariji hrvatskoglagoljski misal s početka 14 . stoljeća, Rim, Biblioteca Apostolica Vaticana, sign. Borg. illir. 4.

MBerl = Berlinski misal, 1402., Berlin, Staatsbibliothek zu Berlin, sign. Ms. Ham. 444.

MVat $_{8}=8$. vatikanski misal, 1435., Rim, Biblioteca Apostolica Vaticana, sign. Borg. Illir. 8.

MNov = Novakov misal, 1368., Beč, Österreichische Nationalbibliothek, sign. Cod. slav. 8 .

MNY = Newyorški misal, sredina 15. st., New York, The Pierpont Morgan Library, sign M. 931.

MRoč = Ročki misal, 1420., Beč, Österreichische Nationalbibliothek, sign. Cod. slav 4.

PsLob = Lobkovicov psaltir, 1359., Prag, Státní knihovna (Lobkovická knihovna), sign. XXIII G 67.

PsFr = Fraščićev psaltir (Psalterium Vindobonense), 1463., Beč, Österreichische Nationalbibliothek, sign. Cod. slav. 77.

\section{LITERATURA}

BAUEROVÁ, H. 2001. K lexikálním archaismům charvátskohlaholských textů. Slavia 70: 291-298.

BIRNBAUM, H. 1996. How Did Glagolitic Writing Reach the Coastal Regions of Northwestern Croatia?. Croatica 42-44: 69-79.

BORYŚ, W. 2007. Čakavske leksičke studije. Praslavensko naslijeđe u čakavskome leksičkome fondu. Zagreb: Matica hrvatska.

CEJTLIN 1977. = ЦЕЙТЛИН, Р. М. 1977. Лексика старославянского язика. Москва: Наука. [CEJTLIN, R. M. 1977. Leksika staroslavjanskogo jazika. Moskva: Nauka.]

DESPODOVA 1993. = ДЕСПОДОВА, В. 1993. Влијането на великоморавската средина врз македонската средновековна писменост. Реферати на македонските слависти за XI мегуународен славистички конгрес во Братислава. Скопје: Македонска академија на науките и уметностите - Македонски славистички комитет, 55-62. [DESPODOVA, V. 1993. Vlijaneto na velikomoravskata sredina vrz makedonskata srednovekovna pismenost. Referati na makedonskite slavisti za XI 
međunaroden slavistički kongres vo Bratislava. Skopje: Makedonska akademija na naukite i umetnostite - Makedonski slavistički komitet, 55-62.]

HERCIGONJA, E. 1975. Srednjovjekovna književnost. Povijest hrvatske književnosti, knjiga 2. Zagreb: Liber - Mladost.

HRISTOVA 2004. = ХРИСТОВА, И. 2004. Преславизмите в апостолските четива в хръватските глаголически мисали и бревиарии. [HRISTOVA, I. 2004. Preslavizmite $\mathrm{v}$ apostolskite četiva $\mathrm{v}$ hъrvatskite glagoličeski misali i breviarii. Preslavska knižovna škola 7: 42-56.]

HCJ 2014 = HRVATSKI CRKVENOSLAVENSKI JEZIK 2014. Gadžijeva S.; A. Kovačević; M. Mihaljević; S. Požar; J. Reinhart; M. Šimić; J. Vince. Zagreb : Hrvatska sveučilišna naklada - Staroslavenski institut.

HUŤANOVÁ, J. 1998. Lexika starých slovanských rukopisov. Bratislava: Filozofická fakulta Univerzity Komenského - Kultúrny zväz Bulharov a ich priatel'ov na Slovensku.

LbVOV 1966. = ЛЬВОВ, А. С. 1966. Очерки по лексике памятников старославянской письменностн. [LbVOV, A. S. 1966. Očerki po leksike pamjatnikov staroslavjanskoj pis'mennosti. Moskva: Nauka.]

LbVOV 1968. = ЛЬВОВ, А. С. 1968. Чешско-моравская лексика в памяатниках древнерусской пис̈менности. Славянское язикознание. VI международний съезд славистов. Праг 1968. Москва: Наука, 316-338. [LbVOV, A. S. 1968. Češsko-moravskaja leksika v pamjatnikah drevnerusskoj pis'mennosti. Slavjanskoe jazikoznanie. VI meždunarodnij s'ezd slavistov. Prag 1968. Moskva: Nauka, 316-338.]

MAREŠ, F. V. 1956. нед'九да цв'Етьнаґ. Slavia XXV/2: 258-259.

MARTI 1994. = МАРТИ, Р. 1994. Проблеми на значението на славянската лексика от Кирило-Методиевско време. Problemi na značenieto na slavjanskata leksika ot Kirilo-Metodievsko vreme. Paleobulgarica/ Старобългаристика XVIII/4: 23-39. [MARTI, R. 1994. Problemi na značenieto na slavjanskata leksika ot Kirilo-Metodievsko vreme. Paleobulgarica/Starobălgaristika XVIII/4: 23-39.]

MIHALJEVIĆ, M. 2007. Morfološka (tvorbena) raščlamba leksika najstarijih hrvatskoglagoljskih fragmenata. S. Vranić, (ur.). Zbornik u čast Ivi Lukežić. Rijeka: Filozofski fakultet - Odsjek za kroatistiku, 231-247.

MIHALJEVIĆ, M. 2011. Bilješke o jeziku Drugoga beramskoga brevijara. Tabula 9: 126-139.

MIHALJEVIĆ, M. 2017. Leksik 2. beramskog brevijara u usporedbi s Rječnikom crkvenoslavenskoga jezika hrvatske redakcije. Filologija 69: 53-59.

MIHALJEVIĆ, M. 2018. Jezik najstarijih hrvatskoglagoljskih rukopisa. Zagreb: Hrvatska sveučilišna naklada - Staroslavenski institut.

MIHALJEVIĆ, M. 2018. (u tisku). Pregled preslavizama u hrvatskoglagoljskim tekstovima: 1. preslavizmi bez obzira na kontekst. Zbornik radova u povodu 60. rođendana Iskre Hristove Šomove.

MIHALJEVIĆ, M.; ŠIMIĆ, M. 2013. Preslavizmi u hrvatskoglagoljskim tekstovima. $A$ tko to ide. Hrvatski prilozi XV. međunarodnom slavističkom kongresu, 11-23.

MILČETIĆ, I. 1895. Čakavština kvarnerskih otoka. Rad JAZU 121: 92-131. 


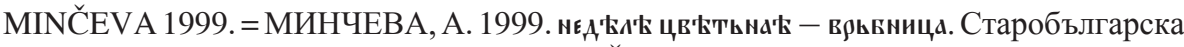
литература 31. Софија, 105-115. [MINČEVA, A. 1999. Nedělě cvětnaě - vrbbnica. Starobălgarska literatura 31. Sofija, 105-115.]

NEDELJKOVIĆ, O. 1970. Staroslavenska sinonimika i problem staroslavenskih jezičnih redakcija. Radovi Filozofskoga fakulteta u Zadru 8-9: 41-54.

PANTELIĆ, M. 2013. Senjski Lobkovicov psaltir iz 1359. godine. Hrvatsko glagoljsko srednjovjekovlje. Zagreb: Kršćanska sadašnjost - Družba sestara milosrdnica svetog Vinka Paulskog, 505-520.

PETROVIĆ, I. 1988. Prvi susreti Hrvata s ćirilometodskim izvorištem svoje srednjovjekovne kulture. Slovo 38: 5-54.

REINHART, J. 1980. Methodisches zu den lexikalischen Bohemismen im TschechischKirchenslavischen am Beispiel der Homilien Gregors des Grossen. Wiener slavistisches Jahrbuch 26: 46-102.

RIBAROVA 2005.a. = РИБАРОВА, 3. 2005.а. Јазикот на македонските црковнословенски текстови. Скопје: Македонска академийа на науките и уметностите. [RIBAROVA, Z. 2005.a. Jazikot na makedonskite crkovnoslovenski tekstovi. Skopje: Makedonska akademija na naukite i umetnostite.]

RIBAROVA, Z. 2005.b. Uz nekoliko kršćanskih termina u makedonskim crkvenoslavenskim tekstovima. S. Damjanović (ur.). Drugi Hercigonjin zbornik. Zagreb: Hrvatska sveučilišna naklada, 367-372.

RIBAROVA 2009. = РИБАРОВА, 3. 2009. За неколку христијански термини во македонските црковнословенски текстови во споредба со хрватскглаголските. Палеословенистички студии. Скопје: Институт за македонски јазик »Крсте Мисирков«, Посебни изданија, кн. 63, 145-151. [RIBAROVA, Z. 2009. Za nekolku hristijanski termini vo makedonskite crkovnoslovenski tekstovi vo sporedba so hrvatskoglagolskite. Paleoslovenistički studii. Skopje: Institut za makedonski jazik »Krste Misirkov«, Posebni izdanija, kn. 63, 145-151.]

RIBAROVA 2010. = РИБАРОВА, 3. 2010. Белешки за лексиката на псалтирните стихови во Григоровичевиот паримејник. Прилози посветени на академик Петар Хр. Илиевски. Скопје: Македонска академија на науките и уметностите, 105-114. [RIBAROVA, Z. 2010. Beleški za leksikata na psaltirnite stihovi vo Grigorovičeviot parimejnik. Prilozi posveteni na akademik Petar Hr. Ilievski. Skopje: Makedonska akademija na naukite i umetnostite, 105-114.]

RIBAROVA, Z. 2017. Staroslavenska leksikografija: sadašnje stanje i perspektive. Filologija 69: 83-97.

STANKOV 2016. = СТАНКОВ, Р. 2016. Древнеболгарские переводные тексты и проблема лексических моравизмов. Софија: Университецко издателство »Св. Климент Охридски«. [STANKOV, R. 2016. Drevnebolgarskie perevodnye teksty i problema leksičeskih moravizmov. Sofija: Universitetsko izdatelstvo »Sv. Kliment Ohridski«.]

ŠIMIĆ, M. 2000. Leksik hrvatskoglagoljskoga psaltira. Doktorska disertacija u rukopisu. Zagreb: Filozofski fakultet Sveučilišta u Zagrebu. 
ŠIMIĆ, M. 2004. Moravizmi u hrvatskoglagoljskim tekstovima. M. A. Dürrigl, M. Mihaljević, F. Velčić (ur.). Glagoljica i hrvatski glagolizam, Zbornik radova s međunarodnoga znanstvenog skupa povodom 100. obljetnice Staroslavenske akademije $i$ 50. obljetnice Staroslavenskog instituta (Zagreb-Krk 2.-6. listopada 2002.). Zagreb - Krk: Staroslavenski institut - Krčka biskupija, 577-586.

ŠIMIĆ, M. 2008. Leksik psaltira Akademijina brevijara (III c 12). Slovo 56-57: 531-544.

ŠTEFANIĆ, V. 1969. Glagoljski rukopisi Jugoslavenske akademije: I. dio. Zagreb: Jugoslavenska akademija znanosti i umjetnosti.

Preslovljeni Temporal Drugoga beramskog (ljubljanskog) brevijara. Zagreb: Staroslavenski institut. Badurina Stipčević, Vesna; Botica, Ivan; Dimitrova, Margaret; Dürrigl, Marija-Ana; Hristova Šomova, Iskra; Kovačević, Ana; Kuhar, Kristijan; Mihaljević, Milan; Mokrović, Ljiljana; Požar, Sandra; Radošević, Andrea; Šimić, Marinka; Vela, Jozo; Vince, Jasna; Vučković, Josip; Zubčić, Sanja; Žagar, Mateo. 2015. (dostupan na https://beram.stin.hr/hr/transliteration/53).

\title{
Sum mary \\ Marinka Šimić
}

\section{MORAVISMS IN THE SECOND BERAM (LJUBLJANA) BREVIARY}

The original translation of the Old Church Slavonic biblical texts as it is known, in particular the aprakos, psalms, and apostles, was modified in Moravia, although it has not yet been investigated to what extent. A certain number of lexemes were probably taken from the West Slavic languages. Although there is no evidence of contact between Croats and the Moravian mission in historical sources related to the oldest Cyrillic period of Slavic literacy, it can be assumed that this influence occurred after the expulsion of Slavic students from Moravia, if not earlier. Among other things, this is confirmed by the preserved Moravisms in Croatian Glagolitic texts, that is, words that are archaic in the canonical Old Church Slavonic texts. Most of them appear in our older manuscripts, fragments, missals and breviaries: $d r(e) v l e$, drbkola, uedriti, ešutb, mbša, mito, natruti, raspeti, rêsnota, siko, sbnbmb, šui etc. Some of these lexemes also appear in the Second Beram Breviary: drev'lê, dreselb, drkola, kokošb, pastirb, pênezb, derivatives of the root rêsn-, etc. Although the issue of lexical moravisms in Croatian Glagolitic monuments is not completely systematized and defined, the author presents a list of possible moravisms in the Second Beram (Ljubljana) Breviary, with an analysis of their meaning. The paper also explores the difference in the number of moravisms between the 1st and 2nd parts of the breviary and the relationship between this layer of lexemes in this manuscript and the oldest Croatian Glagolitic fragments.

Keywords: moravisms; lexicon; Church Slavonic language of the Croatian Redaction; Second Beram (Ljubljana) Breviary

\author{
Marinka Šimić \\ Old Church Slavonic Institute \\ Zagreb (Croatia) \\ marinka.simic@stin.hr
}

